\title{
12
}

\section{Common property conflict and resolution: Aboriginal Australia and Papua New Guinea}

\section{Kilyali Kalit and Elspeth Young}

It is often assumed that customary concepts of common property must hamper development, and must be eradicated in favour of more individualistic ownership which promotes entrepreneurial approaches and wealth generation. Such assumptions are not new. History presents some strong supporting evidence for their validity, but also raises questions, particularly in relation to equity in resource distribution. In Scotland, for example, the transformation two centuries ago from the communally based run-rig system to the enclosure of the land into individual plots laid the basis for land improvement, agricultural intensification and the introduction of new crops and livestock. Without such changes the population could not have sustained itself, and these new forms of resource management fostered wide-ranging development. However there were also some disadvantages. Many people became landless and were forced either to seek subsistence land elsewhere, usually in ecologically marginal areas, or to migrate to distant lands such as Australia or Canada. More commonly, they moved to the cities to become factory workers in the burgeoning industries of the period. While many of those displaced reaped undoubted economic benefit these changes certainly caused some social dislocation which, although healed by time, must have initally made a significant impact. This agricultural intensification also generated some long-term changes which have been detrimental to the Scottish environment as a whole. 
Commitment in today's industrialised world to the positive benefits of individualisation of property is almost universal. However this doctrine also has wider implications. Because resources are traded on a global scale, the interests and ideas of the industrialised world directly impinge on people from other societies where industrialisation is still a relatively recent process. As Baines (1989) points out, there is widespread feeling among agents of economic development that such a process is constrained by traditional systems of land and sea tenure and that customary resource management systems are largely irrelevant. In the Pacific pressures to transform common property resource holdings to more individualistic forms of ownership are strong and are causing concern for indigenous peoples. Key stakeholders in resource use-the state and, through its arrangements with external financial agencies, organisations such as the World Bank or the International Monetary Fund, development companies and other interested non-indigenous people-have been the main instigators of change. In Papua New Guinea, for example, the World Bank in collaboration with the government has worked tirelessly to encourage conversion of customary group tenure into some form of freehold, involving legislation for customary land registration. Although efforts towards conversion of customary land started in the 1950s the process has never been finally resolved. The most recent attempt (in 1996) under the auspices of the Land Mobilisation Program had to be called off even before making it to Parliament, due to outright rejection by the public, demonstrated through violence and loss of life.

Such concerns and conflicts are not restricted to Melanesia, Micronesia, and Polynesia. They are also supremely important in the industrialised Pacific countries of Australia and New Zealand, both of which have indigenous minority populations which have retained a strong commitment to common resource property concepts and whose customary tenure systems have received only limited recognition under the laws of the state.

Key questions concerning the change from common resource property concepts to more individually defined resources include the following

- who would benefit most from these changes-indigenous customary landholders, the developers, or the state?

- would these changes lead to better or worse distribution of development benefits (jobs, income, control over resources) within the customary landholding group?

- is the type of development driving these transformations- 
capitalistic/individualistic rather than communally-based with sustenance derived from both monetary and nonmonetary activity - ultimately the most sustainable for such Pacific indigenous societies?

- can these concepts of resource property be reconciled so that development is supported? Can viable alternative solutions, recognising both systems, be created?

This chapter focuses primarily on the last of these questions. It refers to local level examples of how indigenous communities have responded to the demands of both communal and individual property definitions, and it examines these within the broader regional frameworks required for people to make these adjustments in ways that promote the future sustainability of their societies. While the two Pacific indigenous groups referred to here (Aboriginal Australians in remote areas and Papua New Guineans) are very different, some common themes can be identified. These relate to the definition of common property resources and traditional ecological knowledge, pressures to change these exerted by commercial resource developments, and the methods devised by indigenous people for coping with the ensuing conflicts.

\section{Relevant common resource property concepts}

Concepts of resource property lie on a continuum ranging from unfettered resources, which users may exploit freely for their own benefit with no consideration for others or for longer-term sustainability, to absolute private ownership, in which a single individual exercises complete exclusionary control over the use of the resources (Bromley 1991). Between these two extremes are communally-owned resources (the group uses the resource according to agreed rules designed to sustain all its members and maintain the future viability of the resource), publicly-owned resources (under state or national jurisdictions), and leased resources (individuals or groups hold tenure for an agreed limited period and are subject to certain restrictions on how to use these assets).

For Australian and Pacific indigenous societies communal ownership is the principal form of common resource property holding. This contrasts with the principal forms of tenure recognised in industrialised societies-public, private and leasehold tenures. The latter forms of resource ownership are largely individualistic. Australian and Pacific indigenous societies have not, despite many misconceptions, held 
their land as a free good, the uncontrolled use of which was seen to lead to the 'tragedy of the commons' (Hardin 1968). Their common property concepts follow distinct rules agreed to within that particular society. Incoming settlers, then largely of European and Anglo-Celtic origins, generally ignored the prior existence of these forms of tenure, a basic failure which has been a common characteristic of colonial occupation over the last five centuries (see, for example, Bromley 1991; Berkes and Farvar 1989, Grima and Berkes 1989, and Ostrom 1990). This failure, a major source of conflict, has had dire consequences.

Colonial settlers in Australia wrongfully assumed that the land was terra nullius, a place that belonged to no one and was therefore free to be taken over by any interested settler. For over 200 years the resource rights and beliefs of indigenous Australians have been largely discounted and they have had little opportunity to share in the benefits flowing from resource development. Only in recent decades, following passage of Land Rights legislation in the Northern Territory in 1976, have some Aboriginal people been able to regain control over customary land and negotiate for a share in monetary benefits from development. And it has only been in the 1990s, with the Mabo decision and subsequent passing of the Native Title Legislation, that the fundamental misconception of terra nullius has been legally overturned. While this clearly has implications for resource development the practical consequences are still to be clarified, although mineral resources will still be subject to separate claim by the state.

In Papua New Guinea, in contrast, customary property rights, explicitly recognised under the country's legal framework, extend over at least 97 per cent of the country's land area and most of its forest. The remaining area is 'referred to as alienated land because it was bought or taken away from its customary owners' (Clarke et al. 1996:1). Indigenous kinship groups control land use and natural resource management. As in Australia the state also claims interest in mineral rights over both customary and non-customary land. Pressures to suppress the detrimental characteristics of common resource property regimes in favour of more individually-defined systems are strong. Both countries also demonstrate that forms of resource tenure-communal, state and private-can overlap, and reconcilation of the differences between them becomes very difficult. As Berkes and Farvar (1989) suggest, finding satisfactory ways of dealing with such overlap is a key challenge to resolving resource development conflicts. 
Underlying all of these questions is the key point of how common property concepts and rights are defined. As far as commercial resource development is concerned, the main issues concern the spatial definition of boundaries between property groups, the determination of membership of the groups, and the characteristics of various mechanisms by which these groups exercise control over their resource. Unless these issues are clearly understood no practical resolutions can be devised.

\section{Boundaries and group membership}

The perception that Australian Aborigines did not define their territorial boundaries but were 'aimless wanderers' was, from early European settlement, a remarkably persistent myth. On the contrary, as later anthropological and linguistic studies (such as Tindale 1972, Peterson 1976) have demonstrated, Aboriginal groups held communal responsibility for broad but distinct areas of land and resources and exercised that responsibility through both traditional ecological knowledge and their cultural and spiritual knowledge. Recent land rights recognition and legislation, based primarily on establishment of proof of the customary ownership of claimants (Young 1992b), has brought the issue of spatial definition of these 'countries' into sharp focus. As a result, non-indigenous understanding of Aboriginal boundary parameters has greatly increased. As Sutton's recent exploration of boundary issues reveals (Sutton 1995), researchers have become increasingly convinced both of their overall complexity, and less willing to see them as rigid lines dividing different 'countries' from one another. Similar complexities have emerged in attempts to define group members, commonly called 'traditional owners'. Here, as Hiatt et al. (1984) discuss, the lineage group remains the core of those claiming to hold customary responsibility for a particular 'country'. However, there is, and probably always has been, some fluidity in group membership, reflecting demographic changes in pre-contact times and, more recently, population changes resulting from dispossession and mobility. As with spatial boundaries it is the decision of the group itself which counts in determining who does, or does not, belong.

Papua New Guinean indigenous societies also define their spatial boundaries but, as continuing inter-group conflicts show, areas of contention have always been present and still remain. Systems of land tenure in Papua New Guinea are complex and vary greatly. Highland societies, for example, distinguish between territory and property'territory is a group resource, whereas occupied or improved land, 
used for gardens, houses, and other individual or group purposes, is property' (Brown 1978:113). As this implies, while the whole is common resource property, there are degrees of difference in the way that ownership is demonstrated. Through regular use, land-inevitably the most fertile-can become individual property. This obviously has implications for resource development, whether through cash-cropping, forest logging or claims for mineral development compensation. Membership of the extended kin group responsible for the whole region is inextricably linked into such tenure systems through reciprocity and resource sharing. That membership, in terms of rights to land, can be extended beyond the immediate lineage to include other long-term residents who originally were granted only temporary resource rights (Brookfield and Brown 1967). Banks's (1996) recent discussion on compensation and relocation payments for the Porgera gold-mine in Papua New Guinea shows that the incorporation of these more broadly defined lineage groups into the agreement has posed very difficult questions for the company concerned.

\section{Control}

A common characteristic of indigenous regimes in both Papua New Guinea and Aboriginal Australia is the existence of distinct control, both on group activities and on individual use of resources within the group's area. In addition, this control was exercised through internally upheld rules and behavioural norms with which all responsible members of the group were familiar. As Gibbs and Bromley (1989) comment, such control is essential if common resources are to be properly managed. Transgression against the agreed rules, such as allowing your livestock to devastate your neighbours' crops (in Papua New Guinea) or visiting spiritual sites from which, for gender or group affiliation reasons, you should be excluded (in Aboriginal Australia) were punishable. Thus control was internally defined and exercised, a situation which, as Ostrom (1990) has stressed, provides much greater group cohesiveness and stability than one in which control is externally imposed, such as from the state.

\section{Common resource property definition and development}

Increased recognition of the complexities of boundary and group definitions has been accompanied, somewhat ironically, by increased pressure to make firm decisions on these parameters. Davis and Prescott's (1992) analysis of Australian Aboriginal frontiers and 
boundaries provides an obvious example of how one resource developer has tried to exert such pressure. This research study, financed by a major mineral development company, set out to map and define contemporary Aboriginal territories, with a view to providing a definitive text which could be used by both present and future developers in determining with whom they must negotiate over shares in resource rights. As Sutton's (1995) detailed éxpose of this study describes, not only did this study include glaring inaccuracies in definition but it also raised ethical problems because it imposed external control over systems which should be internally determined.

Development companies in Papua New Guinea have also been eager to determine rigidly which common resource properties will be affected by their activities (such as from mining), and would prefer that their negotiations with traditional owners be restricted to the members of core groups. This would obviously, as Power (1995) argues, suit them better. He suggests that the rightful landowners should be identified as early as possible, before a project begins. He feels that this would avoid the proliferation of claims of ownership and demand for increased royalty shares once high levels of production are achieved, as has occurred in the Kutubu project.

However, rigid definition of affected areas and of those deserving compensation has its pitfalls. It may well cut out people whose claims are well-founded. Subsequent problems arising with compensation from large-scale mining developments such as Ok Tedi or Porgera show that the dangers of such approaches are very real.

\section{Aboriginal Australia: common resource property and development}

The history of land tenure change in Australia can be classified, as far as Aborigines are concerned, into two distinct periods. First there was the period of alienation and privatisation, during which large-scale dispossession occurred and direct evidence of Aboriginal common resource property was hidden 'underground'. Second, there was the period of land rights recognition, reinforced by legislation, when Aboriginal concepts of landownership came firmly back into focus. Both of these periods emphasise not only the importance of land tenure transformation in relation to economic use and control over natural resources but also, as Sutton (1995) has recently stressed, the highly political nature of these changes. During the first period, which lasted from first contact until around 1970, state and private forms of 
property ownership prevailed and indigenous interests in resource development benefits were ignored and went uncompensated. It is the second period, commencing approximately 25 years ago with the adoption by the Federal government of policies supporting Aboriginal land rights, which is of greatest interest in this discussion. This period has seen significant concessions on Aboriginal Land Rights (over 15 per cent of the Australian continent, primarily in remote areas, is now under Aboriginal ownership-Figure 12.1-but also the beginning of processes which have spread resource development benefits more equitably to customary owners. It has also shown how common resource property concepts and more individual forms of ownership might be reconciled. The following discussion focuses on the pastoral sector, with brief references to human settlement, which pervades all resource use.

Figure 12.1 Aboriginal land in Australia

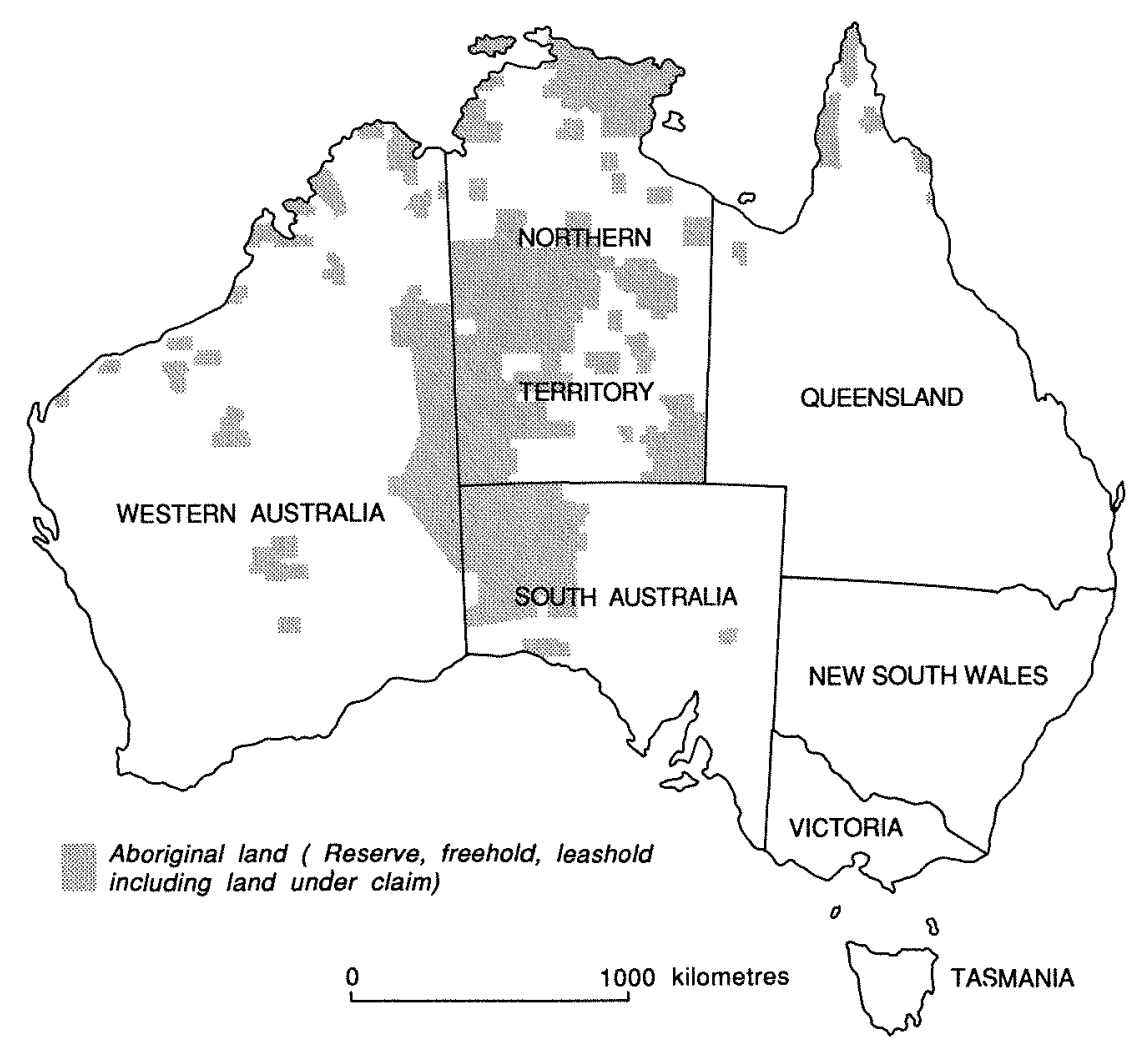




\section{Settlement}

The use of land for settlement is the most basic form of resource use. The last 25 years have seen a marked reoccupation of many of the remotest parts of Australia by Aboriginal groups who have regained legal title to their customary lands which they had earlier been encouraged and sometimes forced to leave (see, for example, Young 1992a; Australia 1987; Cane and Stanley 1985). Centralised administrative settlements, a prime instrument of earlier assimilation policies, have declined as people have returned to the land, establishing well over 200 'outstations' or 'homeland centres' in central Australia alone. As Taylor (1992) has demonstrated for the Northern Territory, this has led to a marked dispersal of population. The locations of these outstations accord as closely as possible with customary human/land linkages. However, because of the need to accommodate to non-indigenous systems of land tenure and to meet modern demands for services, they do not fit completely with these patterns. Thus, for example, people may have been unable to establish their new camps at a chosen waterhole either because that waterhole lay on land now legally alienated to the state or a non-indigenous developer or landholder, or because the water resource was neither large nor predictable enough to support the returning group. Attempts to find alternative ground water supplies were often frustrated because drilling in the chosen site was unsuccessful or the water supplies were non-potable because of their high salt content. The existence of roads and tracks, services such as schools and clinics, permanent houses and the provision of electricity, telecommunications and other increasingly vital attributes of modern lifestyles have also influenced site choice. Administrative pressures for centralisation rather than dispersion have been strong, with persuasion sometimes applied through legal restrictions on land settlement and less directly through introducing user-pays programs for electricity and water at price rates which are beyond the pockets of most Aboriginal outstation dwellers. Many outstation sites are therefore compromises, located on or near customary land but accessible to externally provided services.

The use of the land around outstations also reflects this compromise. Subsistence hunting and foraging is practised as closely as possible to customary norms with particular individuals holding detailed knowledge and responsibilities. But other outstation residents with less obvious traditional claims to these resources are not excluded. Over time, they may well gain most of the basic spiritual and ecological lore already held by the recognised customary landholders. They may even, as 
traced for the Anmatyerre people to the northwest of Alice Springs (Young 1987) be fully accepted as customary resource owners. And physical access for vehicles, vital to the success of contemporary hunter-foragers, inevitably means that track networks also play a significant role in determining where people go and what they harvest.

These compromises present challenges to the Aboriginal groups concerned, and also to the administrative authorities charged with providing them with basic services. For the people the challenge has been to approximate their chosen customary settlement patterns as closely as possible. For the administrators, it is the need to deal efficently with scattered, highly mobile populations who still have prime needs for services such as power, education, and health to be satisfied (Young and Doohan 1989).

\section{Pastoralism}

Government policies fostering Aboriginal development have generally followed the paradigms of the industrialised world, stressing monetary economic gain as the only path to the future. In the pastoral industry commercially-oriented development, in which Aboriginal groups would acquire properties and run them, like their nonindigenous neighbours, as successful money-making ventures has been generally promoted. For many complex reasons-historical, political, environmental, social and cultural-few Aboriginal properties have fulfilled that promise (Young 1995).

Over the last 20 years more than 40 pastoral properties have been acquired by Aboriginal groups, primarily through government land purchase funding. Although encouraged, and sometimes coerced, into managing these properties commercially, many new Aboriginal owners have had different priorities for the use of the land, priorities which demonstrate adaptation between common resource property regimes and more individualised forms of tenure. As recorded in a number of studies conducted in the decade from 1978 (Young 1988a and 1988b), properties in the Northern Territory were able to convert themselves to freehold title through claims lodged through the Northern Territory Aboriginal land rights legislation. Once released from restrictions imposed through leasehold regulations, the people could therefore use the land as they wished. Their earlier common resource property regimes often began to surface. This resulted in the dispersal of extended family groups from centralised homestead settlements, where they had worked for the former non-indigenous owner, to 
scattered 'outstations' located in the traditional country of each group; the development of multiple small-scale cattle enterprises, ecotourism ventures and arts and craft ventures focusing on these outstations; the re-emergence of subsistence hunting and foraging as a major activity; and the maintenance of cultural activities. In the case of Mt Allan (Fig. 12.2), following a successful land claim the Anmatyerre people split into three major groups, one centred on the existing homestead and the others, associated with honey ant and emu dreaming respectively, in new outstations located within their customary 'countries' and accessible to important cultural sites about which they were concerned. As discussed elsewhere (Young 1987) the Aboriginal interpretation of responsibility for the country within the former Mt Allan pastoral

\section{Figure 12.2 Anmatyerre and non-Aboriginal delineations of property on Mount Allan}

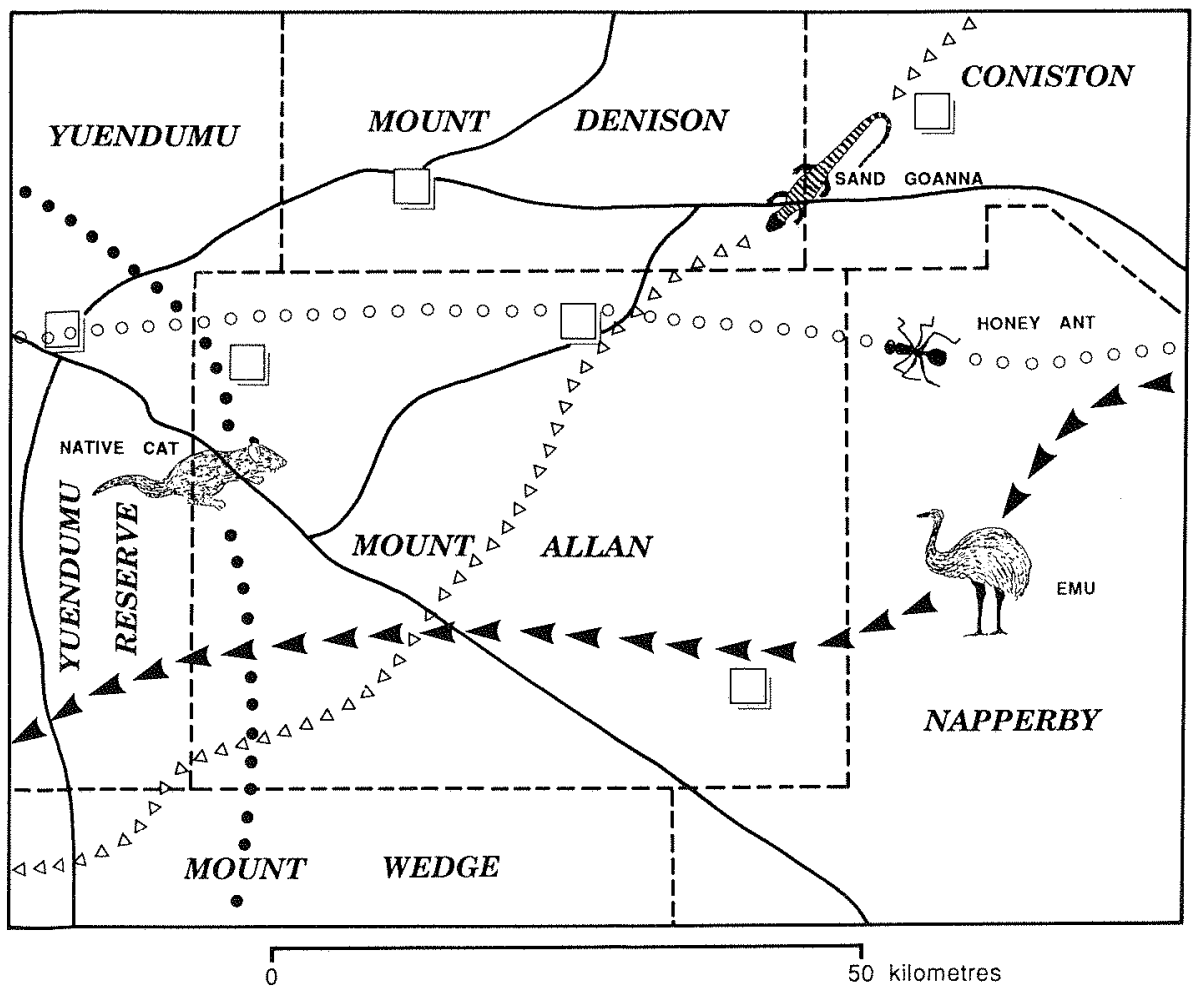


lease focuses on a number of ancestral beings whose activities trace 'tracks' in the landscape. Non-indigenous concepts of land tenure in the same area, in contrast, emphasise introduced boundary and infrastructure definition-fences, roads and substantial permanent buildings.

In some cases, such as the former Utopia cattle station to the northeast of Alice Springs, significant reduction in stocking rates has led to a marked regeneration of natural vegetation and the rehabilitation of wildlife habitats, with a resultant improvement in the potential of the country for subsistence hunting and foraging. Here most of the Alyawerre people abandoned the former centralised settlement in favour of a number of outstations located in the traditional country of each group concerned. Many established reputations as artists both in the national and international scene (NT Department of Primary Production 1983). To many non-indigenous people, including pastoralists and government officials, developments such as those on Mt Allan and Utopia have been wholly negative because they undermine the continuing advancement of commercial pastoralism. However, they have had a positive effect on many Aboriginal families, now living lifestyles which they find much more attractive than their former ones.

Even outside the Northern Territory, where legislation allowing the conversion of these leases to freehold title has not been established, adaptations have occurred. Aboriginal pastoralists in the Kimberley, for example (Davies and Young 1995, 1996), are increasingly exploring land management regimes which combine subsistence hunting and gathering with commercial cattle production and the development of tourist enterprises. Cattle production has become more intensive, emphasising the production of smaller numbers of larger, more valuable animals in the more accessible parts of properties, while the remainder of the land may be spasmodically used for subsistence fishing and wildlife hunting; and tourist expeditions to the spectacular ranges, gorges and waterholes of this remote far northern region.

An interesting prospect for a region such as this is the possibility of actual land redistribution to reflect these changes in use. Where there are adjoining Aboriginal cattle stations, communities might negotiate to remove their lease boundary fences and amalgamate their accessible lands along the road to form an intensive cattle production. section. The 'backblocks' could then be devoted to subsistence and other alternative uses (Sullivan 1995). These new multiple use efforts are usually based on Aboriginal concepts of the common resource and 
the diversification which they have introduced is arguably better for many marginal grazing lands (Young and Ross 1994).

\section{Common property and individual resource tenure: achieving resolution in Aboriginal Australia}

Common themes in the above examples suggest some factors essential for the reconcilation of the differing constraints which common property and individualised forms of tenure have imposed on Aboriginal groups. These include

- the determination of the group itself, operating from a grassroots level, to establish its own priorities and select what they want from both systems

- the existence of a political climate which allows for effective decision-making on these issues within the community

- the provision of facilitating mechanisms, including regional supporting organisations, to enable community landholding groups to talk to, and negotiate with, outside stakeholders to ensure that their interests are taken into account

- the provision of funding, both to establish and maintain such buffer organisations and to support the efforts of the local community groups.

In each example, the Aboriginal groups concerned were very highly motivated in their search for re-identification with customary land from which they had been at least partially dislocated. They deliberately sought resource management strategies which would emphasise traditional cultural and economic values, seeing these generally as more important than resource harvesting for economic gain. And these strategies were adopted during the time when the political climate overtly supported Aboriginal self-determination. Moreover these were very coherent communities, strongly linked through kinship and with a clear view of their status and role as customary landholders. Decision-making accorded closely with traditional value systems and pressures to oppose these were relatively weak. Such characteristics foster coherent community decisionmaking. There is, however, no guarantee that they will continue to be maintained. Contemporary emergence of arguments about who has the right to speak for land, who belongs to the group, and over whether Native Title has survived or been extinguished by subsequent land alientation, suggest that the disruption of such approaches is now much more obvious. 
The pastoral and settlement land management strategies adopted by these groups were also supported by a number of outside agencies, both government and non-government. Principal government agencies included federal and state departments of Aboriginal Affairs, in some cases enthusiastic about encouraging outstation development and solving remote-area service delivery problems. More recently, resource management agencies have begun to develop programs designed to assist the specific needs of Aboriginal land managers. The latter have included programs which undoubtedly recognise the importance of strategies which combine common property regimes with more individual forms of tenure-community management of endangered wildlife species, community programs to eradicate feral animals and introduced plant species, and programs to support subsistence-type pastoral projects rather than stressing commercial viability. These developments have been very positive. However, it must be acknowledged that government support for these initiatives has often been quite grudging and there are many key individuals in these agencies who see such efforts as unnecessary pandering to indigenous interests.

Non-government agencies have been principally the Aboriginal land councils. Over the last decade these organisations, funded by government and, where royalty agreements have been negotiated, through the proceeds of resource development on Aboriginal land (normally from mining), have extended their original focus on the conduct of land claims to include land management. Many of these approaches have been quite innovative. The Alice Springs-based Central Land Council, for example, has established a continuing study of how Aboriginal environmental perceptions of the arid zone differ from those commonly held by others (Rose 1995). These include Aboriginal concern over wholesale eradication of feral animals such as rabbits and cats, now often part of their 'bush tucker'; their interest in the short-term effects of seasonal climatic change (such as what plants thrive, and where animals congregate after rain) rather than recognition of the long-term consequences of erosion stemming from overgrazing and other misuse of the environment; their belief that failure to maintain customary use of fire, particularly obvious in areas from which the Aboriginal presence has been discouraged, is responsible for turning the country to 'rubbish'; and, of universal importance, the need to recognise and respect the cultural value of the land, not only at specific 'sacred sites' but also in its entirety. In all of these cases common property resource concepts are paramount. 
The Central Land Council has also established a pilot project in culturally and environmentally appropriate land assessment, a move which offers new potential for improving Aboriginal and non-Aboriginal communication on rangeland valuation. This project exemplifies the possibilities arising from blending Aboriginal traditional ecological knowledge with scientific approaches and technologies (Mahney et al. 1996) It also highlights in a practical way the benefits from encouraging collaboration between scientists and Aboriginal resource managers. Both of these efforts have been supported by tapping into government funding resources such as the National Landcare program and the Land and Water Research and Development Corporation. Not all Aboriginal agencies can hope to do this and the struggle to obtain sufficient support to extend such initiatives to other parts of the country remains intense.

\section{Papua New Guinea: custom and the capitalist system}

Most of Papua New Guinea's population continue to live in rural communities, not effectively linked to the major urban centres by communication or transport infrastructure. The essential government services are inadequate and in some cases non-existent. This means that most of the people continue to derive their livelihoods from their land and its associated resources. In these communities, custom continues to play a key role in the management of common property resources.

Despite relative isolation, many of these communities are undergoing a massive transition from a subsistence to a monetary economy. Large-scale resource exploitation projects are being established in commercial agriculture, fisheries, forestry, minerals and petroleum. These projects are all having a significant impact on traditional social structures and customary resource management systems. They have been welcomed by rural communities in the hope of development. For a villager in Papua New Guinea, development is seen in terms of employment opportunities, spin-off business opportunities, funding, and the opening up of access roads, aid posts, and primary schools, and hard cash (perhaps from resource royalties). Project agreements signed between the developer and the local landowning clan specify benefit packages. These packages, however, vary between and within sectors, with greater benefits on the whole flowing through some large-scale mining agreements than occur 
under smaller-scale forestry agreements. Although people know that resource exploitation has had a negative impact on traditional social structures and has irreversibly damaged the environment, their patterns of thinking and subsequent actions in approving projects is very rational. Without these agreements some of these communities would never have the opportunity to see any positive changes at all, or even be able to send their children to school. Thus, as Hayne states, 'they will take those actions which they think will yield them the largest net advantage' (1994:5).

Resolution of the contradictions between customary land tenure and the individualisation of resource property is essential if the problem of providing Papua New Guineans with sustainable livelihoods for the future is to be solved. Attitudes towards this are ambivalent. Legal and official policy statements uphold customary tenure, but consecutive governments in the last twenty years have advocated economic development through the capitalist or free market system. This poses a development dilemma which is crucial for the future of Papua New Guinea (Baines 1989:273).

In some cases appropriate programs for administration, marketing, and credit have been established to promote export-oriented agricultural production on communally-owned land. This has encouraged individualisation of common property resources, especially for the establishment of permanent tree crops such as coffee. Smallholders produce much of Papua New Guinea's pyrethrum and well over 60 per cent of the total volume of coffee.

Forestry provides a different example. Here development is preceded by the Government Forest Authority signing a Forest Management Agreement with a Incorporated Land Group (ILG), incorporated under the Land Groups Incorporation Act of 1974. The Forestry Act itself sets out a preference for resource owners to form representative groupings in line with this Act. Despite the ILGs being officially recognised as the instruments for utilisation and conservation of natural resources, government assistance in this area is minimal. Landowners have to take responsibility for their own incorporation, and in general they are forced to seek assistance in this process from the developers themselves. This gives the developers a strong hold over the ILGs. The landowners are left vulnerable to outside influences and may be rushed into making decisions that are not mutually beneficial to other members of the community or their tribe. Primary rights may be denied and in most cases secondary right-holders are excluded from participation, involvement, 
and benefit sharing. In the resultant conflicts, relations between the landowners themselves, with the government, and with investors often deteriorate and are increasingly becoming areas of concern.

Land reform, involving the individual registration of customary land, presents an alternative to the promotion of development under existing customary tenure. This has so far failed and indications are that prospects for Papua New Guinea's development through land resource utilisation seem poor.

The government is caught in a contradictory situation. The Land Mobilisation Program (LMP) was designed to contribute to economic growth through productive use of the land resources throughout the country, whilst promoting equity, employment, participation and social stability (World Bank 1989). This assumes that land resources are now inadequately utilised and that outputs generated from customary land are insufficient. As the dominance of smallholder production in pyrethrum and coffee shows, this is questionable. Papua New Guinean communities have adapted very well in meeting the demands imposed on them by the capitalist system. The other underlying assumption is that customary tenure is the prime constraint to economic development. Other structural problems that hinder development include availability of credit; provision of appropriate extension services; poor market access; lack of efficient technology; and poor communication and infrastructure. Even if all the customary land were registered, there is no gurantee that rural production would increase. These structural problems would also need to be addressed.

As the outright public rejection of land mobilisation suggests, pursuing this approach is not a realistic option. Instead the government needs to undertake a massive awareness program on the existing legal and policy provisions on customary tenure and explain why the registration of customary land is necessary. By educating landowners on these issues people might make more informed decisions on the conversion of customary land. In other words, working within the existing policy and legal framework, which explicitly recognises customary tenure, is to be preferred (Kalit 1996). This, in turn, will depend upon recognising and dealing with some threats and constraints to the overall sustainability of Papua New Guinea's rural communities. The current ad hoc approach to development is a prime example. In most cases it is local leaders and the educated élite who invite the government or introduce potential developers to possible projects. This unplanned and uncontrolled approach, which is already 
leading to the approval of many projects in Papua New Guinea, is potentially very damaging both to the country's overall sustainability and to the welfare of many of its people.

\section{Sustainable resource management: a new approach}

As most of the resources of Papua New Guinea-its land, forests and fisheries-are common property resources owned by kinship groups, any sustainable development effort must focus on assisting the resource owners to manage their resources on a sustainable basis. The customary tenure means that sustainable development is only practicable when it is endorsed by local communities and groups (Redclift and Saga 1994:13). One of Papua New Guinea's National Development Goals states that development should take place primarily through the use of indigenous forms of social, political and economic organisations. In reality, the government has failed to advocate development through this approach. Colonial and independent governments have only paid lip service to resource owner involvement in decision-making, in management and control and in sustainable resource management (Holzknecht 1995:24). While the government's 1994 approval for the development of a National Sustainable Development Strategy offers some hope for the practical implementation of these earlier national goals much needs to be done, particularly in the realm of indigenous involvement in resource management. Recent reforms to the provincial government system, which target greater empowerment, involvement and participation of local people as well as delivery of services, are a positive move. It will take some time for the restructured system to work and even then it is questionable whether it will be efficient.

Meanwhile local landowners will continue to pursue their endeavours on an ad hoc basis. Innovative systems need to be put in place immediately to assist the landowners to better manage their resources. An approach for promoting sustainable management of forest resources through customary means is discussed below.

\section{A case for a forest resource owner development agency}

Forest resources have significant value to the clan groups whose land has always provided materials for housing, decoration, gardening and more recently a means of gaining cash. Papua New Guinea is now facing an era where there is a global interest in the marketing, and at the same time conservation, of its forests. 
The demand for forest resources is expected to grow as supplies from the other Southeast Asian and South Pacific countries dwindle and it is hoped that this feature will enhance Papua New Guinea's bargaining power in the future. From 1991 to 1995 the National Forestry and Conservation Plan, under the auspices of the internationally supported Tropical Forest Action Plan, has provided the impetus for reformation of the forestry sector. Now a new policy, legislation and administrative structure for ensuring proper management of these resources is in place.

The 1994 National Forestry and Conservation Plan Review, while acknowledging that the Program had been successful in achieving its objectives at the national government level, found that it was less successful in enhancing resource owner involvement and field operations (UNDP 1994a:5). This review made specific recommendations to assist landowners during its second phase, including

- rationalisation of an accelerated landowner awareness/ mobilisation program

- strengthening local level capacity in forest management

- non-timber forest products, and biodiversity products and service evaluation.

The Landowner Involvement component of the Forest Management and Planning Project (Holzknecht 1995) proposed a range of ways to increase people's participation in, and management of, their forest resources. The key emphasis was on establishing and operating the Incorporated Land Groups. It also focused on mechanisms for advice and information sharing by landowners. The 1994 UNDP Mission Report on Sustainable Development also made recommendations for reformation of policy and institutions to cater for empowerment and active participation by the rural people. One mechanism suggested was the establishment of a Rural Trust to support non-government organisations and local initiatives (UNDP 1994b).

Papua New Guinea's National Forest Authority will have an important extension function in teaching landowners the principles and practice of sustainable forest management. But who will discuss what non-logging options, such as conservation or agricultural development, they have? Who can help them carry out such ventures? And what will happen to the large flows of funds derived from logging, much of which already goes to wrong people or is wasted on immediate consumption or inappropriate investments? Who can 
advise landowners on how best to invest these revenues in sustainable agriculture or other investments to secure their future needs? (World Bank 1993).

These issues could be dealt with under a forest revenue system through which some of the revenues earned from logging would be distributed to landowners to be spent however they wished, and the remainder deposited in a trust fund to be devoted to longer-term projects. Despite the political sensitivity surrounding this proposal, it seems worth suggesting that the funds be administered for the landowners by an independent organisation.

Such a Trust Fund could only be effectively operated if there were a competent agency to help landowners prepare and appraise project proposals. There is a strong argument for setting up an independent and visibly landowner-oriented statutory corporation, with its trust fund, which would clearly be divorced from the regulatory and enforcement activities of the National Forest Authority (World Bank n.d.).

The proposed agency might have four components.

1. A development Trust Fund, which would primarily be financed from logging revenues, but could also be readily used to channel funds, as matching grants, from any other sources (such as external donors). The Trust Fund would be administered as a single fund, although a separate account would be established for each ILG, which would maintain exclusive ownership of such funds.

2. An executive board (with suitable representation from Government, private sector, non-government organisations and landowners) to approve the use of these funds.

3. A technical secretariat, whose functions would be to help landowners incorporate new Land Groups; negotiate project agreements; prepare suitable projects and to present them to the board for approval. The secretariat would act as a catalyst, helping landowners to mobilise technical support from government line agencies and private consultants. But it would also require core in-house expertise.

4. A trust fund administrator (probably an international accounting firm) of sufficient repute to be acceptable to both landowners and donors.

It is envisaged that the agency would have the capacity to offer technical advice to ILGs on a full range of options on how best to use their logging revenues. These might include: reafforestation, 
agriculture development, community services (health, education and water supply), fisheries development and infrastructure development (roads and bridges).

The corporation would have an assured source of funds, if the suggestion for withholding a portion of forest revenue is accepted. If not, it is possible that landowners might voluntarily entrust a portion of their revenues to such a fund, particularly if some kind of matching grant were available to supplement their own funds. In either case, the agency would need to perform well to maintain landowners support.

The lack of a mechanism for helping landowners to manage their resources is also recognised as a constraint in other sectors such as agriculture and mining (Holzknecht 1995, Samana 1993). Landowners need incentives to conserve areas of biological interest. These incentives could be in the form of

- alternative income opportunities

- social services tied to conservation covenants

- direct compensation (rent) payments for maintaining conservation areas.

Similar needs occur in mining, petroleum, fisheries and agriculture, where there are no agencies competent to assist landowners in managing their resources on a sustainable basis. It would nevertheless, be sensible to pilot the proposal in the forestry sector first before trying to expand it to other sectors.

\section{Lessons from comparison}

Comparison between the initiatives described in Aboriginal Australia and the options currently open to customary landholding groups in Papua New Guinea show the following to be of prime importance.

First, landowner awareness is now well established for many remote Aboriginal groups but still requires substantial effort in Papua New Guinea. Landowners need to know all the development options they have, the reasons behind any major changes in these options, and all the existing facilities and mechanisms for encouraging sustainable resource management.

Second, governments should accept their role in assisting land and resource management in culturally appropriate ways which incorporate common property resource concepts. They should demonstrate this commitment by allocating more technical and financial resources. The government in Papua New Guinea has yet to move in this direction. In Australia, while some positive initiatives have been taken to 
support the efforts of Aboriginal Australians, the framework, particularly in current climate of government cutbacks and economic rationalism, is very fragile.

Lastly, there is a need to establish and fund 'buffer' organisations which can stand legally between people, governments and developers, with responsibility to all stakeholders and with the expertise to give advice as required. An innovative development approach like that proposed above for Papua New Guinea gives serious attention to landowner participation. Aboriginal organisations in Australia, particularly the Land Councils in the Northern Territory and Trust Fund organisations provide some interesting models.

Although the contrast between the operation of such organisations in an industrialised country like Australia and a country with limited industrialisation like Papua New Guinea is marked, many of the principles remain the same. The developers and the government should transmit significant amounts of the profits from resource exploitation not only directly to the affected landowners, but also to organisations designed to assist those landowners to make informed decisions about their future. 


\section{References}

Australia, House of Representatives Standing Committee on Aboriginal Affairs, 1987. Return to Country: the Aboriginal Homelands movement in Australia, Final Report, Australian Government Publishing Service, Canberra.

Baines, K., 1989. 'Traditional resource management in the Melanesian South Pacific: a development dilemma', in F. Berkes (ed.), Common Property Resources: ecology and community-based sustainable development, Belhaven Press, London:273-95.

Banks, G., 1996. 'Compensation for mining: benefit or time-bomb? The Porgera gold mine', in R. Howitt, J. Connell and P. Hirsch (eds), Resources, Nations and Indigenous Peoples: case studies from Australasia, Melanesia and southeast Asia, Oxford University Press, Melbourne.

Berkes, F. and Farvar, M.T., 1989. 'Introduction and Overview,' in F. Berkes (ed.), Common Property Resources, Belhaven Press, London.

Bromley, D., 1991. Environment and Economy: property rights and public policy, Blackwell, Cambridge, Mass.

Brookfield, H. and Brown, P., 1967. Struggle for Land, Oxford University Press, Melbourne.

Brown, P., 1978. Highland Peoples of Papua New Guinea, Cambridge University Press, Cambridge.

Cane, S. and Stanley, O., 1985. Land Use and Resources in Desert Homelands, North Australia Research Unit, Australian National University, Darwin.

Clarke, B., Crocombe, R., Lakau, A., Larmour, P., and Macintyre, M., 1995. Customary Land Tenure Systems in PNG, AusAID, Canberra.

Davies, S.J. and Young, E., 1995. 'Sustainability, development and rural Aboriginal communities', Australian Geographer 26(2):150-155.

_- 1996. 'Taking centre stage: Aboriginal strategies for redressing marginalisation', in R. Howitt, J. Connell and P. Hirsch, (eds), Resources, Nations and Indigenous Peoples: case studies from Australasia, Asia and the southwest Pacific, Oxford University Press, Melbourne.

Davis, S. and Prescott, J.R.V., 1992. Aboriginal Frontiers and Boundaries in Australia, Melbourne University Press, Melbourne.

Denoon, D., Ballard, C., Banks, G. and Hancock., P, (eds), 1995. Mining and Mineral Resource Policy Issues in Asia-Pacific: prospects for the 21st century, proceedings of the conference at the Australian National University, 1-3 November 1995, Division of Pacific and Asian 
History, Research School of Pacific and Asian Studies, The Australian National University, Canberra.

Gibbs, C.J.N. and Bromley, D., 1989. 'Institutional Arrangements for Management of Rural Resources: common property regimes', in F. Berkes (ed.), Common Property Resource, Belhaven Press, London.

Grima, A.P.L. and Berkes, F., 1989. 'Natural resources: access, rights-touse and management', in Common Property Resources, F. Berkes, (ed.), Belhaven Press, London.

Hardin, G., 1968. 'The Tragedy of the Commons', Science 162:1243-8.

Hayne, P. (ed.), 1994. The Economic Way of Thinking, Macmillan, New York.

Heathcote, R.L. and Mabbutt, J.A. (eds), 1988. Land, Water and People: geographical essays in Australian resource management, Allen and Unwin, Sydney.

Hiatt, L. (ed.), 1984. Aboriginal Landowners, Oceania Monograph 27, University of Sydney, Sydney.

Holzknecht, H.A., 1995. 'Forest Management and Planning Project,' Working Papers Produced as part of the Landowner Involvement Component 1993 to 1995, PNG Forest Authority, World Bank and Groome Poyry Ltd.

Howitt, R., Connell, J. and Hirsch, P. (eds), 1996. Resources, Nations and Indigenous Peoples: case studies from Australasia, Melanesia and southeast Asia, Oxford University Press, Melbourne.

Kalit, K., 1996. A sustainable development approach for Papua New Guinea: the landowner support imperative, National Centre for Development Studies, The Australian National University, unpublished.

Mahney, T., Gambold, N., Walsh, F. and Winstanley, D., 1996. 'Looking at country two ways-land resource assessment on Aboriginal lands in Central Australia', Australian Collaborative Land Evaluation Program Bulletin 1:2-5.

Northern Territory Department of Primary Production, 1983. Utopia Land Resources, their Condition, Utilization and Management, Department of Primary Production, Alice Springs.

Ostrom, E., 1990. Governing the Commons, Cambridge University Press, Cambridge.

Papua New Guinea, 1991. Forestry Act 1991, Forest Authority, Hohola.

Peterson, N., (ed.), 1976. Tribes and Boundaries in Australia, Australian Institute of Aboriginal Studies, Canberra. 
Power, A.P., 1995. 'Mining and petroleum development under customary land tenure: the Papua New Guinea experience', in Donald Denoon, Chris Ballard, Glenn Banks and Peter Hancock (eds), Mining and Mineral Resource Policy Issues in Asia-Pacific: prospects for the 21st century, proceedings of the conference at the Australian National University, 1-3 November 1995, Division of Pacific and Asian History, Research School of Pacific and Asian Studies, The Australian National University, Canberra.

Redclift, M., and Saga, C., (eds), 1994. Strategies for Sustainable Development: local agendas for the southern hemisphere, John Wiley and Sons, Chichester, New York, Brisbane, Toronto, Singapore.

Rose, B., 1995. Land management Issues: attitudes and perceptions amongst Aboriginal people in central Australia, Central Land Council, Alice Springs.

Samana, U., 1988. Papua New Guinea: which way?, Arena Publications Association, Victoria.

Sullivan, P., 1995. Beyond native title: multiple use agreements and Aboriginal governance in the Kimberley, Discussion paper 89/1995, Centre for Aboriginal Economic Policy Research, The Australian National University, Canberra.

Sutton, P., 1995. Country: Aboriginal boundaries and land ownership in Australia, Aboriginal History Monograph 3, The Australian National University, Canberra.

Taylor, J., 1992. 'Geographic location and Aboriginal economic status: a census-based analysis of outstations in the Northern Territory', Australian Geographical Studies 30 (2):163-84.

Tindale, N., 1974. Aboriginal Tribes of Australia: their terrain, environmental controls, distribution, limits and proper names, University of California Press, Berkeley.

UNDP, 1994a. Review of the National Forest and Conservation Action Program (NFCAP), Port Moresby.

- 1994b. Yumi Wankain: report of the United Nations joint inter-agency mission to Papua New Guinea on sustainable development, Port Moresby.

World Bank, 1989. Staff Appraisal Report: Papua New Guinea land mobilization project, World Bank, Washington DC.

—_ 1993. Papua New Guinea, Jobs, Economic Growth and International Competitiveness, Agriculture Operations Division, World Bank, Washington DC. 
- no date. Landowner Resources Development Agency, unpublished.

Young, E., 1987. 'Resettlement and Caring for Country', Aboriginal History 11:156-70.

- 1988a. 'Land use and Resources: a black and white dichotomy', in R.L. Heathcote and J.A. Mabbutt (eds), Land, Water and People: geographical essays in Australian resource management, Allen and Unwin, Sydney.

- 1988b. Aboriginal Cattle Stations in the East Kimberley: communities or enterprises?, EKIAP Working Paper 21, CRES, The Australian National University, Canberra.

- 1992a. 'Aboriginal land rights in Australia: expectations, achievements and implications', Applied Geography 12:146-61.

, 1992b. 'Hunter-gatherer concepts of land and its ownership', in $\mathrm{K}$. Anderson and F. Gale (eds), Inventing Places, Longmans, Melbourne.

- 1995. Third World in the First: development and indigenous peoples, Routledge, London.

Young, E. and Doohan, K., 1989. Mobility for Survival: a process analysis of Aboriginal population movement in central Australia, North Australia Research Unit, Darwin, and The Australian National University, Canberra.

Young, E. and Ross, H., 1994. 'Using the Aboriginal rangelands: 'insider' and 'outsider' perceptions', The Rangeland Journal 16(2): 184-97. 